\title{
Tungstate compounds as an alternative to uranyl acetate for enumerating viral-infected prokaryote cells in aquatic systems
}

\author{
A. S. Pradeep $\operatorname{Ram}^{1,3}$, T. Nagata ${ }^{1, *}$, Y. Tomaru ${ }^{2}$, K. Nagasaki ${ }^{2}$ \\ ${ }^{1}$ Centre for Ecological Research, Kyoto University, 2-509-3 Hirano, Otsu, Shiga 520-2113, Japan \\ ${ }^{2}$ Harmful Algal Bloom Division, National Research Institute of Fisheries and Environment of Inland Sea, \\ Fisheries Research Agency, 2-17-5 Maruishi, Hatsukaichi, Hiroshima 739-0452, Japan
}

${ }^{3}$ Present address: Laboratoire de Biologie des Protistes, Université Blaise Pascal (Clermont-Ferrand II), UMR CNRS 6023, 63177 Aubiere cedex, France

\begin{abstract}
We examined whether tungstate compounds (sodium phosphotungstate and sodium silicotungstate) can be used as a safe alternative to uranyl acetate (UA) for the purpose of detecting and counting viruses inside aquatic prokaryotic cells using transmission electron microscopy (TEM). Tungstate compounds used as negative stains at neutral to slightly acidic $\mathrm{pH}$ are less effective in the detection of viral particles inside the cells. However, the use of tungstate compounds at low $\mathrm{pH}$ (3 or 4) substantially improved viral images, being positively contrasted inside the cells. With this improvement, the estimates of the frequency of viral-infected cells derived by the tungstate method agreed well with those determined by the use of UA for both lake and marine waters. We also found that the average burst size of the lake sample differed little between tungstate and the UA approach; however, the average burst size in a marine sample was underestimated by the tungstate method because of the failure to resolve highly packed viral particles. The above results suggest that the use of tungstate compounds at low $\mathrm{pH}$ can be a useful alternative to the UA approach for estimating the frequency of viral-infected cells in aquatic samples, but results on the burst size need to be interpreted cautiously when the burst size is high.
\end{abstract}

KEY WORDS: Tungstate compounds • Uranyl acetate · Transmission electron microscopy · Frequency of viral infected cells $\cdot$ Burst size $\cdot$ Prokaryotes $\cdot$ Viruses

Resale or republication not permitted without written consent of the publisher

\section{INTRODUCTION}

Viruses are the most abundant biological entity in marine and fresh waters and play important roles in nutrient fluxes, food-web dynamics and the maintenance of microbial diversity through selective lysis of host cells (reviewed by Fuhrman 1999, Wommack \& Colwell 2000, Weinbauer 2004). Transmission electron microscopy (TEM) has been a powerful tool with which to determine the frequency of viral-infected cells (FVIC) and to enumerate the number of viral particles inside the cells (burst size); in turn, these variables have been used to evaluate prokaryotic mortality owing to viral infection and viral production rates (Bettarel et al. 2004, Pradeep Ram et al. 2005).

For TEM analyses, viruses and cells are stained using heavy metals because biological materials mainly consist of light elements, being hardly visible under TEM. Among heavy metal stains, uranyl acetate (UA) has been used widely as an effective enhancer of the contrast of intracellular viral images against light background, facilitating the determination of FVIC 
and burst size (Proctor \& Fuhrman 1990, Weinbauer et al. 1993, Jacquet et al. 2005, Pradeep Ram et al. 2005). However, UA contains the fissile isotope (U-235) and radioactive nuclides that emit $\alpha$-particles (U-235 and U-238; IAEA 1996), is highly toxic, and is a product derived from depleted uranium associated with the nuclear fuel cycle. Recently, strict regulations for the use, storage and transport of UA have begun to be enforced in some countries such as Japan and Australia; this tendency could be extended to other countries, with concerns about nuclear security increasing worldwide. Thus, there is a need to develop a method that does not rely on the use of UA.

One potential approach is to use tungstate compounds, which are non-radioactive, non-fissile and less toxic. Investigators have used tungstate compounds for negative staining of viruses and prokaryotic cells (Dykstra \& Reuss 2003). However, to our knowledge, the effectiveness of the use of tungstate compounds for determining FVIC and burst size in aquatic samples has yet to be tested. The goal of this study was to examine the applicability of the tungstate staining technique as a means to detect and enumerate viral particles residing in prokaryotic cells in lake and marine waters.

\section{MATERIALS AND METHODS}

A freshwater sample was collected at a depth of $5 \mathrm{~m}$ (epilimnion) in mesotrophic Lake Biwa, Japan $\left(35^{\circ} 212.93^{\prime} \mathrm{N}, 135^{\circ} 59.90^{\prime} \mathrm{E}\right.$; see Nishimura et al. 2005 for site descriptions), using a Niskin-X bottle on 29 August 2005. A plastic bucket was used to collect a surface marine water sample from a productive embayment, Hiroshima Bay, Japan (34¹6.30' N, $132^{\circ} 16.00^{\prime} E_{\text {; }}$ see Kamiyama et al. 2003 for site descriptions), on 2 August 2006. The water samples were prefiltered through a $200 \mu \mathrm{m}$ mesh screen, followed by prefiltration through GF/F filters (Whatman) to remove large particles that can potentially obstruct the visualization of prokaryotic cells when observed under TEM.

The samples were fixed with formaldehyde ( $2 \%$ final concentration) and stored at $4{ }^{\circ} \mathrm{C}$. Prokaryotic cells were collected on electron microscope grids (400 mesh, carbon-coated Formvar film) by centrifugation (Himac CP $75 \beta$, Hitachi; P40ST Swing-Out-Rotor at $70000 \times g$ for $20 \mathrm{~min}$ at $4{ }^{\circ} \mathrm{C}$ ) according to Sime-Ngando et al. (1996). Triplicate grids were prepared for each sample. Each grid was stained at room temperature $\left(\sim 20^{\circ} \mathrm{C}\right)$ for 30 s with UA (2\%, pH 4) (Sime-Ngando \& Pradeep Ram 2005) or for $60 \mathrm{~s}$ with sodium phosphotungstate (PTA, Agar Scientific) (2\%) or sodium silicotungstate (SST, Sigma) (2\%). The pH of PTA and SST solutions was adjusted to $3,4,5,6$, or 7 using $1 \mathrm{~N} \mathrm{NaOH}$.
The grids were rinsed twice with $0.02 \mu \mathrm{m}$ filtered distilled water to remove excess stains, and dried on filter paper. The samples were examined using a JEOL-JEM 1010 transmission electron microscope operated at $80 \mathrm{kV}$ at a magnification of 20000 to $60000 \times$ in order to distinguish between prokaryotic cells with and without intracellular viruses. A prokaryote was considered infected when at least 5 viruses, identified by shape and size, were clearly visible inside the host cell. At least 500 prokaryote cells were inspected per grid to determine FVIC. Burst size was estimated by enumerating viral particles inside infected cells.

\section{RESULTS AND DISCUSSION}

The FVIC values (expressed as \% of total prokaryotic cells) determined using the conventional UA technique for Lake Biwa and Hiroshima Bay waters were $3.7 \pm 0.1$ and $2.1 \pm 0.1 \%$, respectively (mean $\pm \mathrm{SD}$, $\mathrm{n}=3$ ) (Fig. 1), the former being significantly greater than the latter ( $p<0.003$, ANOVA). The FVIC was then measured using PTA and SST. There was no significant difference in FVIC between PTA and SST measurements $(p>0.05)$; however, both varied depending

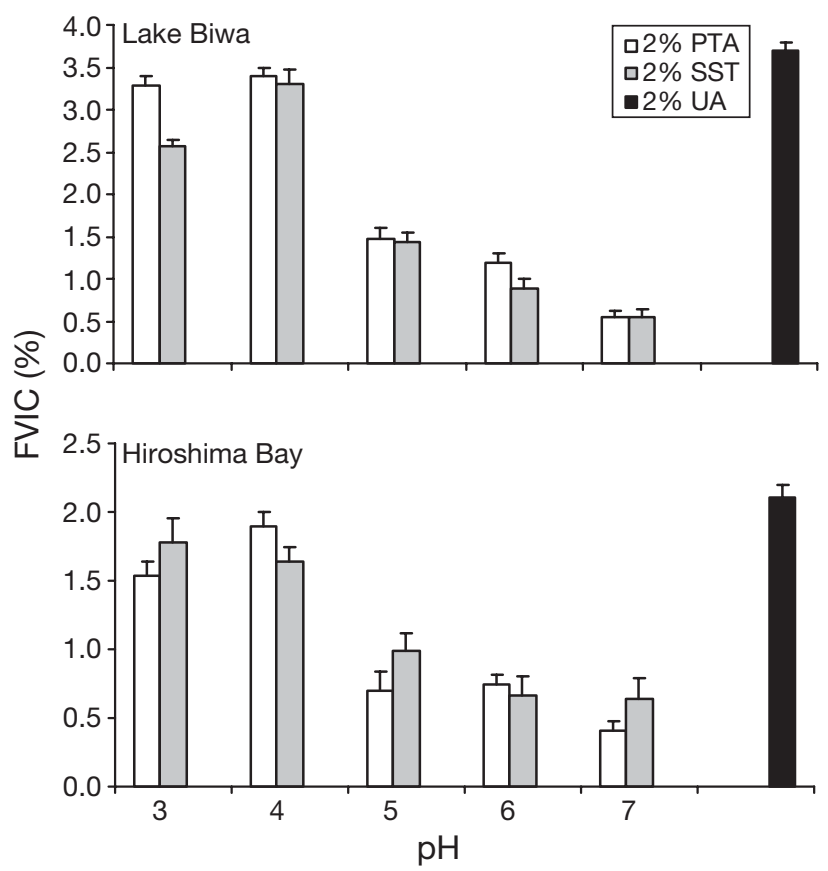

Fig. 1. Comparison of frequency of viral-infected cells (FVIC) (expressed as \% of total prokaryotic cells) determined by TEM using tungstate stains sodium phosphotungstate (PTA) and sodium silicotungstate (SST) at variable $\mathrm{pH}$ (range 3 to 7 ) with that obtained by uranyl acetate (UA). Samples were collected from Lake Biwa and Hiroshima Bay, Japan. Error bars $=+\mathrm{SD}(\mathrm{n}=3)$ 
on the pH. In Lake Biwa and Hiroshima Bay waters, FVIC determined at low pH (3 and 4) was on average 1.68-fold (Lake Biwa) to 1.60-fold (Hiroshima Bay) greater than that obtained at higher $\mathrm{pH}(5,6$ and 7$)$ (Fig. 1). The maximum FVIC was obtained using PTA

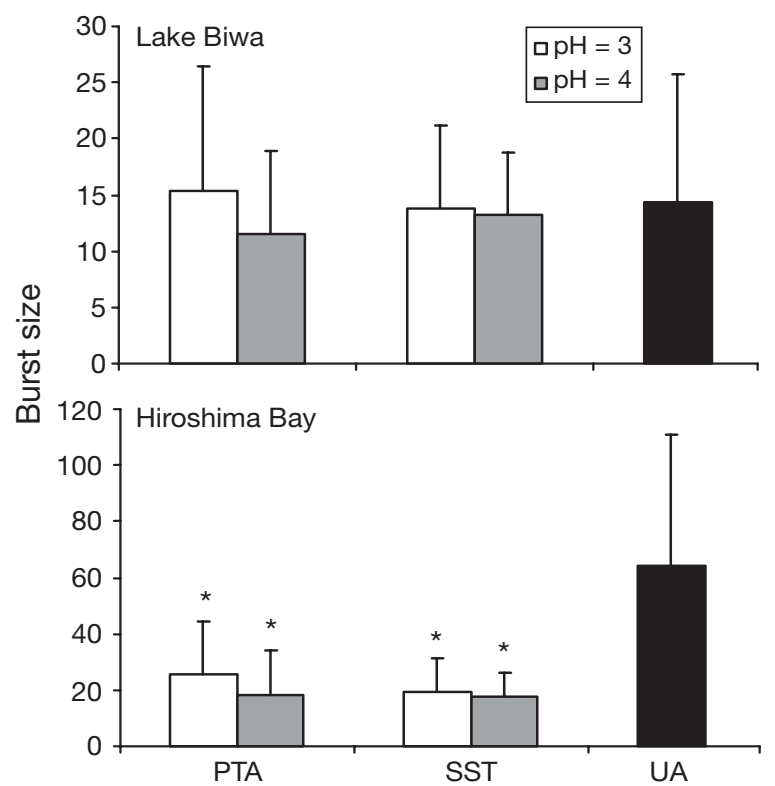

Fig. 2. Comparison of burst size estimates obtained using tungstate stains (PTA and SST, at pH 3 and 4) with that obtained by the conventional UA staining technique. Samples were collected from Lake Biwa and Hiroshima Bay. *: estimates differ significantly ( $p<0.0004$, ANOVA) from those obtained with the UA staining technique. Error bars $=+\mathrm{SD}$

$$
(\mathrm{n} \approx 22 \text { to } 40)
$$

at $\mathrm{pH}=4$, with values of $3.4 \pm 0.1$ and $1.9 \pm 0.1 \%$ for Lake Biwa and Hiroshima Bay samples, respectively; these values did not differ significantly from those obtained using UA ( $p>0.05)$.

The estimates of burst size determined using UA were $14 \pm 11$ (mean \pm SD, $n=40)$ and $64 \pm 46(n=22)$ for Lake Biwa and Hiroshima Bay waters, respectively (Fig. 2), the latter being significantly greater than the former $(\mathrm{p}<0.001)$. For PTA and SST, we determined the burst size only for samples stained at low pH (3 and 4) because viral particles inside the cells were hardly resolved at high $\mathrm{pH}(5,6$ or 7$)$. In Lake Biwa water, the burst size determined by the use of PTA $(15 \pm 11$ and $11 \pm 7$ for $\mathrm{pH} 3$ and 4 , respectively) and SST $(13 \pm 8$ and $13 \pm 6$ for $\mathrm{pH} 3$ and 4 , respectively) did not differ significantly ( $p>0.05$ ) from that obtained using UA. However, in water from Hiroshima Bay, the burst sizes derived for samples stained with PTA $(25 \pm 19$ and $18 \pm 15$ for $\mathrm{pH} 3$ and 4 , respectively) and $\operatorname{SST}(19 \pm 12$ and $17 \pm 9$ for $\mathrm{pH} 3$ and 4 , respectively) were significantly lower than those derived using UA ( $\mathrm{p}<0.0004)$.

Tungstate compounds have been often used at neutral to slightly acidic $\mathrm{pH}$ (6 to 7 ) as negative stains (i.e. darker objects and brighter background); however, PTA and SST have been shown to be stable enough at acidic pH to positively stain objects (Brenner \& Horne 1959, Quintarelli et al. 1971, Curry et al. 2006). In our study, we found that PTA and SST, used as negative stains at neutral $\mathrm{pH}$, are less effective in the detection of viral particles inside cells (Fig. 1). The failure to resolve viruses inside the cells was largely a result of
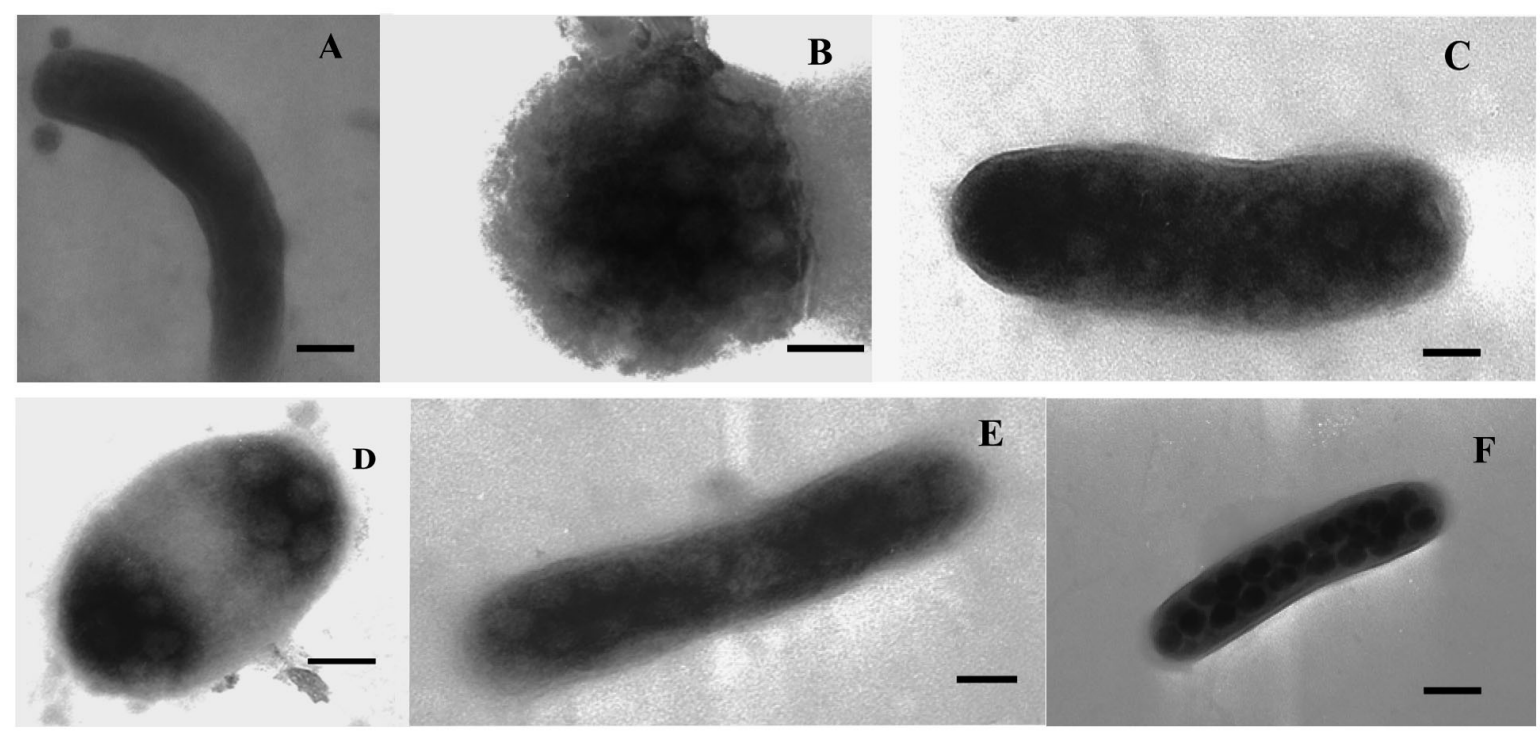

Fig. 3. Electron micrographs of prokaryotes stained by different techniques. (A) PTA at pH 6 (Lake Biwa). Viral particles inside the cells are hardly detectable, even though viral-like particles outside the cells are visible. Detection of viruses inside cells was substantially improved by lowering the $\mathrm{pH}$ for tungstate staining, as indicated in (B) PTA at pH 3 (Lake Biwa), (C) SST at pH 3 (Hiroshima Bay), (D) PTA at pH 4 (Hiroshima Bay) and, (E) SST at pH 4 (Lake Biwa). (F) Lake Biwa sample stained by the conventional UA technique. Scale bars $=100 \mathrm{~nm}$ 
the inference by heavily negatively stained prokaryotic components (Fig. 3A). However, the use of PTA and SST at low $\mathrm{pH}$ (3 or 4) substantially improved the quality of viral images, which were positively resolved inside the cells (Fig. 3B-E). This improvement resulted in higher estimates of FVIC at low $\mathrm{pH}$ ( 3 or 4 ), which did not differ significantly from those determined by the use of UA (Fig. 1). These results suggest that the use of PTA and SST at low pH (3 or 4) could be regarded as a useful alternative to the UA approach in order to visualize and enumerate viral-infected cells in marine and fresh waters.

When tungstate compounds are used at low $\mathrm{pH}$, it presumably interacts with positively charged basic groups of proteins. Lowering the $\mathrm{pH}$ might result in greater stain absorption, but this could also lead to partial degeneration of cell morphology and structure (Quintarelli et al. 1971). Although the intracellular viruses could be detected inside prokaryotic cells using tungstate stains, we noticed that the clarity and resolution are compromised when compared with the images obtained by the conventional UA approach (Fig. 3F). This problem was particularly significant when counting a large number $(>50)$ of viruses in a single cell, which was occasionally encountered in the Hiroshima Bay sample. This failure to resolve heavily packed viral particles explains the lower detection of average burst size when using the tungstate approach, determined for the Hiroshima Bay sample (Fig. 2). Overall, our results suggest that, when used at low $\mathrm{pH}, \mathrm{PTA}$ and SST are reasonably good alternatives to the UA approach for the purpose of determining FVIC in marine and fresh waters. However, results of burst size should be interpreted cautiously, particularly for those samples with high burst sizes. Further refinement of the tungstate approach is needed for clearer visualization of intracellular viruses

Acknowledgements. We thank Dr. Mikal Heldal, University of Bergen, Norway, for his inputs and valuable suggestions. This study was supported by the 21st Century COE program of Kyoto University (A14) and Japan Society for the Promotion of Science (JSPS) grants $(18651007,17201004)$ awarded to T.N. A.S.P.R. was supported by a JSPS Postdoctoral Research Fellowship.

Editorial responsibility: Curtis Suttle, Vancouver, British Columbia, Canada

\section{LITERATURE CITED}

Bettarel Y, Sime-Ngando T, Amblard C, Dolan J (2004) Viral activity in two contrasting lake ecosystems. Appl Environ Microbiol 70:2941-2951

Brenner S, Horne RW (1959) A negative staining method for high resolution electron microscopy of viruses. Biochem Biophys Acta 34:103-110

Curry A, Appleton H, Dowsett B (2006) Application of transmission electron microscopy to the clinical study of viral and bacterial infections: present and future. Micron 37: 91-106

Dykstra MJ, Reuss LE (2003) Biological electron microscopy: theory, techniques, and troubleshooting, 2nd edn. Kluwer Academic/Plenum Publishers, New York

Fuhrman JA (1999) Marine viruses and their biogeochemical and ecological effects. Nature 399:541-548

IAEA (International Atomic Energy Agency) (1996) International basic safety standards for protection against ionizing radiation and for the safety of radiation sources. International Atomic Energy Agency, Vienna

Jacquet S, Domaizon I, Personnic S, Pradeep Ram AS, Heldal M, Duhamel S, Sime-Ngando T (2005) Estimates of protozoan- and viral-mediated mortality of bacterioplankton in Lake Bourget (France). Freshw Biol 50:627-645

Kamiyama T, Arima S, Tsujino M (2003) Characteristics of the distribution of bacteria, heterotrophic nanoflagellates and ciliates in Hiroshima Bay in summer. Fish Sci 69:755-766

Nishimura Y, Kim C, Nagata T (2005) Vertical and seasonal variations of bacterioplankton subgroups with different nucleic acid content: possible regulation by phosphorus. Appl Environ Microbiol 71:5828-5836

Pradeep Ram AS, Boucher D, Sime-Ngando T, Debroas D, Romagoux JC (2005) Phage bacteriolysis, protistan bacterivory potential, and bacterial production in a freshwater reservoir: coupling with temperature. Microb Ecol 50: 64-72

Proctor LM, Fuhrman JA (1990) Viral mortality of marine bacteria and cyanobacteria. Nature 343:60-62

Quintarelli G, Zito R, Cifonelli JA (1971) On phosphotungstic acid staining. J Histochem Cytochem 19:641-647

Sime-Ngando T, Pradeep Ram AS (2005) Grazer effects on prokaryotes and viruses in a freshwater microcosm experiment. Aquat Microb Ecol 41:115-124

Sime-Ngando T, Mignot JP, Amblard C, Bourdier G, Desvilettes C, Quiblier-Lloberas C (1996) Characterization of planktonic virus-like particles in a French mountain lake: methodological aspects and preliminary results. Ann Limnol 32:1-5

Weinbauer MG (2004) Ecology of prokaryotic viruses. FEMS Microbiol Rev 28:127-181

Weinbauer MG, Fuks D, Peduzzi P (1993) Distribution of viruses and dissolved DNA along a coastal trophic gradient in the northern Adriatic Sea. Appl Environ Microbiol 59:4074-4082

Wommack KE, Colwell RR (2000) Virioplankton: viruses in aquatic ecosystems. Microbiol Mol Biol Rev 64:69-114

Submitted: November 6, 2006; Accepted: March 6, 2007

Proofs received from author(s): March 30, 2007 